\title{
Carbohydrate-labeled Fluorescent Microparticles and their Binding to Lectins
}

Timothy L. Kelly, Michael C. W. Lam, and Michael O. Wolf*

Department of Chemistry, University of British Columbia, Vancouver, British Columbia, Canada, V6T

$1 \mathrm{Z1}$

Typical glycosidation procedure. $2.15 \mathrm{~g}(4.4 \mathrm{mmol})$ of 2,3,4,6-tetra-O-acetyl- $\alpha$-D-galactose trichloroacetimidate and $0.45 \mathrm{~g}(1.2 \mathrm{mmol})$ of 1,4-diiodo-2,5-hydroquinone were added to $100 \mathrm{~mL}$ of dry dichloromethane containing crushed $4 \AA$ molecular sieves. The reaction mixture was cooled to -30 ${ }^{\circ} \mathrm{C}$, and $2 \mathrm{~mL}$ of boron trifluoride diethyl etherate added. After stirring for 5 hours at $-30{ }^{\circ} \mathrm{C}$ under a nitrogen atmosphere, the mixture was allowed to gradually warm to room temperature and stirred overnight. At this point the solution was flushed through a Celite plug to remove the sieves, washed with $50 \mathrm{~mL}$ of water, twice with $50 \mathrm{~mL}$ portions of $5 \%$ sodium bicarbonate, $50 \mathrm{~mL}$ of water, dried over anhydrous magnesium sulfate, filtered and concentrated to dryness by evaporation under reduced pressure. The crude product was purified by column chromatography on silica gel using 40:60 ethyl acetate:hexanes as eluent and the resulting solid washed with anhydrous ethanol. This yielded $0.95 \mathrm{~g}$ of 1c $(75 \%$ yield $)$.

\section{Spectroscopic data.}

1a. NMR (400 MHz, $\left.\mathrm{CDCl}_{3}\right) \delta(\mathrm{ppm}): 7.50(\mathrm{~s}, 2 \mathrm{H}), 5.60(\mathrm{~m}, 2 \mathrm{H}), 5.50(\mathrm{~d}, 2 \mathrm{H}), 5.41(\mathrm{~s}, 2 \mathrm{H}), 5.35(\mathrm{t}$, 2H), $4.27(\mathrm{~m}, 2 \mathrm{H}), 4.10(\mathrm{~m}, 4 \mathrm{H}), 2.18(\mathrm{~s}, 6 \mathrm{H}), 2.10(\mathrm{~s}, 6 \mathrm{H}), 2.05(\mathrm{~s}, 6 \mathrm{H}), 2.02(\mathrm{~s}, 6 \mathrm{H})$. ESI-MS (m/z): $1045\left(\mathrm{M}+\mathrm{Na}^{+}\right)$. Anal. $\left(\mathrm{C}_{34} \mathrm{H}_{40} \mathrm{O}_{20} \mathrm{I}_{2}\right) \mathrm{C}, \mathrm{H}, \mathrm{N}$. 
1b. ${ }^{1} \mathrm{H}$ NMR (300 MHz, $\left.\mathrm{CDCl}_{3}\right) \delta(\mathrm{ppm}): 7.43(\mathrm{~s}, 2 \mathrm{H}), 5.29(\mathrm{~m}, 4 \mathrm{H}), 5.15(\mathrm{t}, 2 \mathrm{H}), 4.94(\mathrm{~d}, 2 \mathrm{H}), 4.20$

(m, 4H), $3.95(\mathrm{~m}, 2 \mathrm{H}), 2.14(\mathrm{~s}, 6 \mathrm{H}), 2.08(\mathrm{~s}, 6 \mathrm{H}) 2.04(\mathrm{~s}, 6 \mathrm{H}), 2.02(\mathrm{~s}, 6 \mathrm{H})$. ESI-MS (m/z): 1045 $\left(\mathrm{M}+\mathrm{Na}^{+}\right), 331\left(\mathrm{C}_{14} \mathrm{H}_{19} \mathrm{O}_{9}^{+}\right)$. Anal. $\left(\mathrm{C}_{34} \mathrm{H}_{40} \mathrm{O}_{20} \mathrm{I}_{2}\right) \mathrm{C}, \mathrm{H}, \mathrm{N}$.

1c. ${ }^{1} \mathrm{H}$ NMR (300 MHz, $\left.\mathrm{CDCl}_{3}\right) \delta(\mathrm{ppm}): 7.47(\mathrm{~s}, 2 \mathrm{H}), 5.56(\mathrm{~m}, 2 \mathrm{H}), 5.46(\mathrm{~m}, 2 \mathrm{H}), 5.09(\mathrm{~m}, 2 \mathrm{H})$, $4.92(\mathrm{~d}, 2 \mathrm{H}), 4.20(\mathrm{~m}, 4 \mathrm{H}), 4.09(\mathrm{~m}, 2 \mathrm{H}), 2.18$ (s, 6H), 2.13 (s, 6H), 2.09 (s, 6H), 2.00 (s, 6H). ESI-MS (m/z): $1045\left(\mathrm{M}+\mathrm{Na}^{+}\right), 331\left(\mathrm{C}_{14} \mathrm{H}_{19} \mathrm{O}_{9}{ }^{+}\right)$. Anal. $\left(\mathrm{C}_{34} \mathrm{H}_{40} \mathrm{O}_{20} \mathrm{I}_{2}\right) \mathrm{C}, \mathrm{H}, \mathrm{N}$.

Typical polymerization procedure. To a mixture of $4 \mathrm{~mL}$ toluene and $2 \mathrm{~mL}$ diisopropylamine was added $75 \mathrm{mg}$ of 1,4-dimethoxy-2,5-diethynylbenzene (2), $278 \mathrm{mg}$ of 1c, $20 \mathrm{mg}$ of 1,2,4tribromobenzene $(3), 16 \mathrm{mg}$ of $\left[\mathrm{Pd}\left(\mathrm{PPh}_{3}\right)_{4}\right]$, and $3 \mathrm{mg}$ of $\mathrm{CuI}$. The mixture was stirred under nitrogen for $60 \mathrm{~s}$, and a degassed solution of $0.8 \mathrm{~g}$ sodium dodecyl sulfate in $60 \mathrm{~mL}$ of water added. The yellow suspension was stirred at ca. $70{ }^{\circ} \mathrm{C}$ for 24 hours, at which time it was centrifuged and the supernatant discarded, yielding an orange-brown solid. This was ultrasonicated in $50 \mathrm{~mL}$ of toluene for 30 minutes, centrifuged, and the supernatant again discarded. The washing procedure was repeated with 2:1 toluene:methanol, 1:2 toluene methanol, and again with $50 \mathrm{~mL}$ of toluene. The resultant orange solid was stirred in $50 \mathrm{~mL}$ of a $0.5 \mathrm{M}$ solution of sodium methoxide in methanol for 2 hours, and the reaction subsequently quenched with half-saturated aqueous $\mathrm{NH}_{4} \mathrm{Cl}$. The solid was separated by centrifugation, washed with $50 \mathrm{~mL}$ of water and $50 \mathrm{~mL}$ of methanol, and dried in vacuo. 


\section{Fluorescence Spectra.}

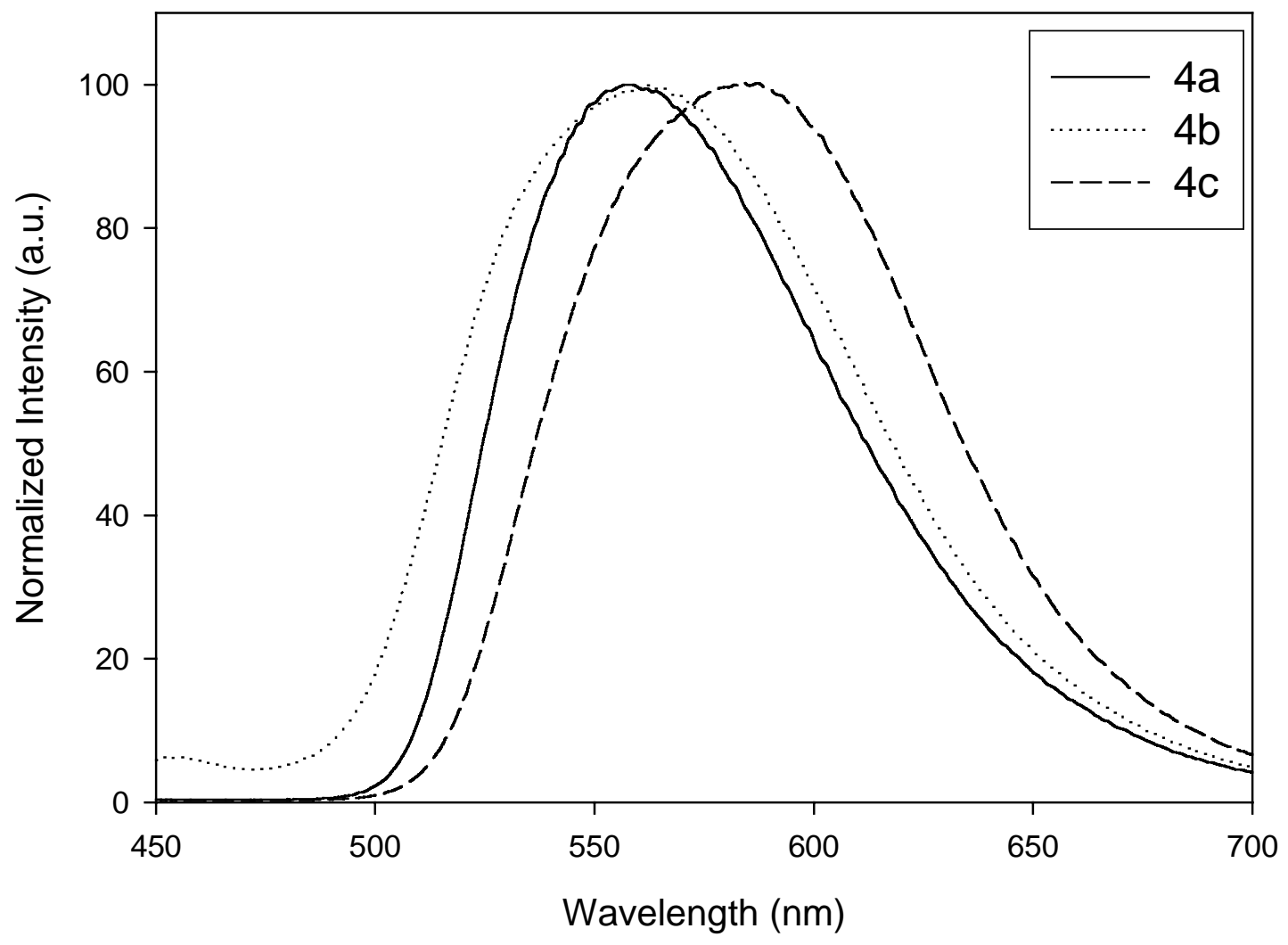

\section{IR Data.}

4a. IR (v, $\left.\mathrm{cm}^{-1}\right)$ : 3421 (s, br); $2204(\mathrm{w}) ; 1637$ (m)

4b. IR ( $\left.v, \mathrm{~cm}^{-1}\right): 3409$ (s, br); $2204(\mathrm{w}) ; 1637$ (m)

4c. IR $\left(v, \mathrm{~cm}^{-1}\right)$ : $3417(\mathrm{~s}, \mathrm{br}) ; 2204(\mathrm{w}) ; 1637(\mathrm{~m})$ 